\begin{tabular}{cc|c}
\hline Tar. Bil. Der. & Journal of Agricultural Sciences \\
& $\begin{array}{c}\text { Dergi web sayfası: } \\
\text { www.agri.ankara.edu.tr/dergi }\end{array}$ & Journal homepage: \\
& www.agri.ankara.edu.tr/journal
\end{tabular}

\title{
Comparison of Microtubule Organization in Arabidopsis thaliana TUB- GFP and MBD-GFP Mutants Exposed to UV-B Radiation
}

\author{
Dongjing MA ${ }^{\text {a, b }}$, Huize CHEN ${ }^{\text {a, b }}$, Rong HAN ${ }^{\text {a, b }}$ \\ aShanxi Normal University, College of Life Science, Linfen, Shanxi, 041000, CHINA \\ ${ }^{\boldsymbol{b}}$ Shanxi Normal University, Higher Education Key Laboratory of Plant Molecular and Environmental Stress Response, Linfen, Shanxi, 041000, \\ CHINA
}

\section{ARTICLE INFO}

Research Article DOI: 10.15832/ankutbd.447642

Corresponding Author: Rong HAN, E-mail: hhwrs1@163.com, Tel: +86 (0357) 2058618

Received: 27 October 2015, Received in Revised Form: 08 January 2016, Accepted: 12 January 2016

\begin{abstract}
Microtubule organization was compared between the Arabidopsis thaliana TUB-GFP and MBD-GFP mutants. Plant height and primary root length were measured, and microtubule dynamics were examined by confocal laser scanning microscopy after UV-B radiation to reveal changes in microtubules. Damage caused by UV-B was comparable between transgenic lines and wild-type plants, although transgenic lines were more sensitive to UV-B than the wild-type. Spots and depolymerization of microtubules were detected in both TUB-GFP and MBD-GFP plants; however, $M B D-G F P$ showed better adaptation of changes induced by UV-B treatment. These results indicated that UV-B inhibits the growth and development of transgenic lines, and the inhibitory effects might result from changes in microtubules, as determined by comparison between the $T U B-G F P$ and $M B D-G F P$ lines.
\end{abstract}

Keywords: Microtubules; UV-B radiation; Arabidopsis thaliana TUB-GFP; Arabidopsis thaliana MBD-GFP

\section{UV-B Işığına Maruz Bırakılmış TUB-GFP ve MBD-GFP Arabidopsis thaliana Mutantlarında Mikrotubulüs Oluşumunun Karşılaştırılması}

\section{ESER BILGISII}

Araştırma Makalesi

Sorumlu Yazar: Rong HAN, E-posta: hhwrsl@163.com, Tel: +86 (0357) 2058618

Geliş Tarihi: 27 Ekim 2015, Düzeltmelerin Gelişi: 08 Ocak 2016, Kabul: 12 Ocak 2016

\section{ÖZET}

Bu çalışmada, TUB-GFP ve MBD-GFP Arabidopsis thaliana mutantlarında mikrotubulüs oluşumu karşılaştırılmıştır. Mikrotubulüslerdeki değişimleri belirlemek üzere UV-B 1şı̆̆ına maruz bırakıldıktan sonra bitki boyu ve ana kök uzunluğu ölçülmüş ve odaktaş lazer görüntüleyici mikroskopla mikrotbulüs hareketi izlenmiştir. Yabani bitkilere gore, transgenik hatlar UV-B'ye daha duyarlı olmasına karşın, UV-B ışığının neden olduğu zararlanmanın transgenik hatlar ile yabani tip bitkilerde karşılaştırılabilir şekilde oluştuğu belirlenmiştir. $M B D-G F P$, UV-B'nin neden olduğu değişikliklere daha iyi uyum göstermesine karşın hem $T U B$-GFP hem de $M B D$-GFP bitkilerinin mikrotubulüslerinde beneklenme ve 
depolimerizasyon olduğu belirlenmiştir. $T U B-G F P$ ve $M B D-G F P$ hatlarının karşılaştırılmasıyla elde edilen bu sonuçlar, UV-B'nin transgenik hatlarda büyüme ve gelişmeyi engellediğini, bu engellemenin mikrotubulüslerdeki değişimlerden kaynaklanabileceğini göstermiştir.

Anahtar Kelimeler: Mikrotubulüsler; UV-B ışını; Arabidopsis thaliana TUB-GFP; Arabidopsis thaliana MBD-GFP

(C) Ankara Üniversitesi Ziraat Fakültesi

\section{Introduction}

Microtubules (MTs) are cylindrical polymers composed of $\alpha$ - and $\beta$-tubulin heterodimers. They are essential for growth and development, participating in several cellular processes such as cell division, intracellular transport, and signal transduction in plants (Granger \& Cyr 2000; Sedbrook 2004). MTs are highly dynamic structures and undergo transitions between states of growth, shrinkage and pause (Kawamura \& Wasteneys 2008). However, abiotic stress is one of the environmental stresses. Plants undergo changes in MTs in response to exposure to abiotic stress. For example, when Lolium rigidum leaves were treated with high pressure, MTs in epidermal cellular arrays changed from random to organized arrangements in cells in which the length was greater than the width (Cleary \& Hardham 1993). When the epidermal cells in the cotyledons of $A$. thaliana are touched by a fine glass or tungsten needles, depolymerization of MTs is induced to form a microtubule-depleted zone surrounding a dense patch of GFP-tubulin beneath the needle tip (Hardham et al 2008). Alterations of turgor disrupt MT organization along with the appearance of crystallization and the distortion of MT arrangement (Shi et al 2011).

Ultraviolet-B radiation (UV-B, 280-320 nm) is an abiotic stress present in the environment. It affects the morphogenesis of plants, modifies plant structure, promotes the production of various secondary metabolites (Rozema et al 1997), and induces changes in the plant cytoskeleton. Previous studies have assessed the effects of UV-B on the cytoskeleton. Han (2002) showed "partition bundle division" in mitotic cells of wheat exposed to UVB. This research showed that protoplast MTs in wheat seedlings were significantly depolymerized under UV-B, leading to the appearance of spots and dispersive MTs (Guo et al 2010). Chen \& Han (2015) showed that actin filaments participate in the process of "partition bundle division" in wheat seedlings injured by enhanced UV-B, supporting that MTs are injured by UV-B treatment (Krasylenko et al 2012). These studies indicate that UV-B has a severe impact on the plant cytoskeleton, especially on the MTs of the cytoskeleton. The damage to MTs affects the growth and development of plants exposed to UV-B radiation.

TUB-GFP was generated by the fusion of green fluorescent protein (GFP) to the $\mathrm{N}$-terminus of $A$. thaliana $\beta$-tubulin 6. Its incorporation into MTs as a functional protein analog allows analysis of changes in MT dynamics in response to low concentrations of drugs in A. thaliana epidermal cells (Nakamura et al 2004; Wasteneys \& Yang 2004). MBD-GFP consists of GFP fused to the microtubule binding domain of microtubule associated protein 4 (MAP4). It allows visualization of MT dynamics not only in mammals, but also in the leaf epidermis of fava bean, A. thaliana, and tobacco. It can label MTs in roots and shape dwarf phenotypes in the plants. The expression of GFP-MBD does not affect the phenotype of the plants (Marc et al 1998; Granger \& Cyr 2000; Granger \& Cyr 2001; Wasteneys \& Yang 2004). Furthermore, GFP, as a reporter, is important for monitoring MT dynamics in $A$. thaliana seedlings, and it allows direct observation of MT dynamics in vivo. The comparison of TUB-GFP and $M B D-G F P$ is useful for the study of MT dynamics and signaling in response to different kinds of stress. However, the effects of TUB-GFP and MBD-GFP on MTs under UV-B treatment are unclear. Here, we used $A$. thaliana TUB-GFP seedlings and $A$. thaliana $M B D-G F P$ seedlings to compare MT dynamics in response to UV-B treatment. 


\section{Material and Methods}

\subsection{Plant materials and growth conditions}

Wild-type (Arabidopsis thaliana L. Col-0), TUB$G F P$, and $M B D-G F P$ plants were used. Seeds were surface-sterilized with $1 \%$ sodium hypochlorite for 5 min and rinsed several times with sterilized water. Sterilized seeds were germinated on plates containing $1 / 2$ Murashige and Skoog medium (Hopebio) with $1 \%$ $\left(\mathrm{w} \mathrm{V}^{-1}\right)$ sucrose at $4{ }^{\circ} \mathrm{C}$ for 3 days, and plants were grown at a temperature of $22{ }^{\circ} \mathrm{C}$ and $60-80 \%$ humidity under a photoperiod of $16 \mathrm{~h}$ light and $8 \mathrm{~h}$ dark $(100-$ $120 \mu \mathrm{mol} \mathrm{m}^{-2} \mathrm{~s}^{-1}$ ) placed vertically for 4 days.

\subsection{Ultraviolet-B radiation treatment}

There were two treatments with three replicates as follows: wild-type, TUB-GFP and $M B D-G F P$ without UV-B treatment; and wild-type, TUB-GFP and $M B D-G F P$ with UV-B treatment. UV-B lamps (Huaqiang, $40 \mathrm{~W}$ ) were set vertically above the plates. The intensity was controlled by modifying the distance between the lamp and the plates. The dose was $4.53 \mathrm{~kJ} \mathrm{~m}^{-2} \mathrm{~d}^{-1}$ (4 h) for 6 days to reach $27.2 \mathrm{~kJ}$ $\mathrm{m}^{-2}$ (Krasylenko et al 2012; Krasylenko et al 2013).

\subsection{Plant height and primary root length quantification}

At 6 days after UV-B treatment, 20 seedlings per replicate were randomly selected from each plate, and plant height and primary root length were recorded.

\subsection{In vivo microtubule observation}

Before the observation, seedlings were placed in the darkroom for at least $12 \mathrm{~h}$ under standard growth conditions (Voigt et al 2005). The morphologic variations of MTs were observed using a confocal laser scanning microscope (FV-1000, Olympus, Japan). Images were analyzed using the FV10ASW 1.7 Viewer supplied with the confocal laser scanning microscope and Photoshop CS5.

\subsection{Statistical analysis}

Data analysis was performed with SPSS 17.0 and Original 8.0. Statistical significance was estimated at $\mathrm{P}<0.05$ according to Duncan's multiple range test. Data are expressed as the mean $\pm \mathrm{SD}$.

\section{Results}

3.1. Comparison between the phenotypes of TUB$G F P$ seedlings and MBD-GFP seedlings exposed to $U V-B$ radiation

Figure 1a shows the appearance of clustered leaves and short petioles in plants without UV-B treatment in $T U B-G F P$ compared with wild-type plants. $M B D-G F P$ was similar to the wild-type, as reported previously (Granger \& Cyr 2001) (Figure 1a). Figure $1 \mathrm{~b}$ shows dwarf phenotypes and smaller leaves in plants exposed to UV-B in TUB-GFP; clustered leaves and shorter petioles were more obvious than those observed in TUB-GFP in Figure 1a. Figure $1 \mathrm{~b}$ shows the inhibitory effect of UV-B on $M B D-G F P$ compared with $M B D-G F P$ in Figure 1a. However, the inhibitory effects on TUB-GFP were more distinct than those on $M B D-G F P$. Figure $1 \mathrm{~b}$ shows the curled-down leaf phenotype of wildtype seedlings compared with that of seedlings in Figure 1a.
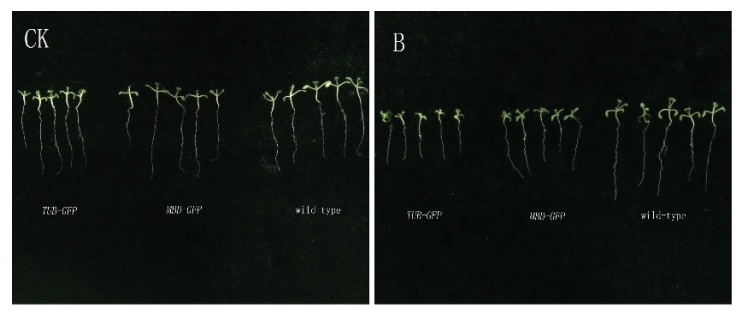

Figure 1- Comparison between TUB-GFP Arabidopsis seedlings and MBD-GFP Arabidopsis seedlings exposed to UV-B radiation; a, Without UV-B treatment (CK), the Arabidopsis seedlings from left to right are $T U B-G F P, M B D-G F P$, and wild-type; b, With UV-B treatment (B), the Arabidopsis seedlings from left to right are $T U B$ $G F P, M B D-G F P$, and wild-type

Şekil 1- UV-B Işığına maruz bırakılmış TUB-GFP Arabidopsis fideleriyle ve MBD-GFP Arabidopsis fidelerinin karşılaştırılması; a, UV-B ışı̆̆g uygulanmamış (CK), soldan saga doğru TUB-GFP, $M B D-G F P$ ve yabani Arabidopsis fideleri; $b, U V-B$ ışı̆̆ uygulanmış (B), soldan saga doğru TUB-GFP, MBD-GFP ve yabani Arabidopsis fideleri 
3.2. Comparison between plant height and primary root length of TUB-GFP and MBD-GFP exposed to $U V$ - $B$ radiation

Plant height and primary root length in the presence or absence of UV-B were randomly measured in the present study. In Figure 2, quantitative analysis showed that $T U B-G F P$ plants were significantly shorter than wild-type and $M B D-G F P$ plants, whereas plant height was comparable between $M B D-G F P$ and wild-type plants that were not exposed to UV-B radiation. Under UV-B radiation, the plant height of $T U B-G F P$ showed the greatest reduction. $M B D-G F P$ plants were shorter than wild-type plants. The plant height was significantly changed compared with that of the control $(\mathrm{P}<0.05)$.

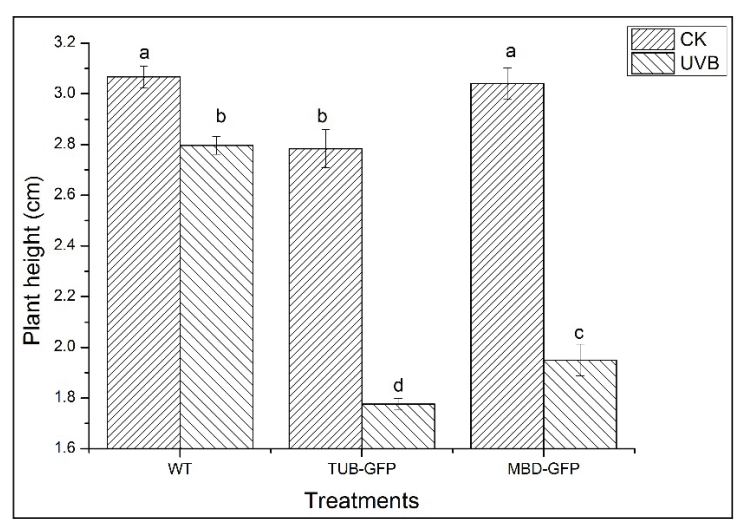

Figure 2- Comparison between the plant height of $T U B-G F P$ and $M B D-G F P$ exposed to UV-B radiation, data represent the mean $\pm \mathrm{SD}(\mathrm{n}=3)$

Şekil 2- UV-B ışı̆̆ına maruz bırakılmış TUB$G F P$ ve $M B D-G F P$ bitkilerinin bitki boylarinin karşılaştırılması, ortalama $\pm S D(n=3)$

The effects of UV-B on primary root length in $T U B-G F P$ and $M B D-G F P$ were also investigated (Figure 3). Quantitative analysis revealed that the primary root length of $T U B-G F P$ was significantly shorter than that of others without UV-B, and the primary root length of $M B D-G F P$ was not significantly different than that of the wild-type plants. In plants exposed to UV-B radiation, the primary root length of $T U B-G F P$ was decreased.
The primary root length of $M B D-G F P$ was also decreased, although it was greater than that of $T U B-$ $G F P$. The primary root length was significantly changed compared with that of the control $(\mathrm{P}<0.05)$.

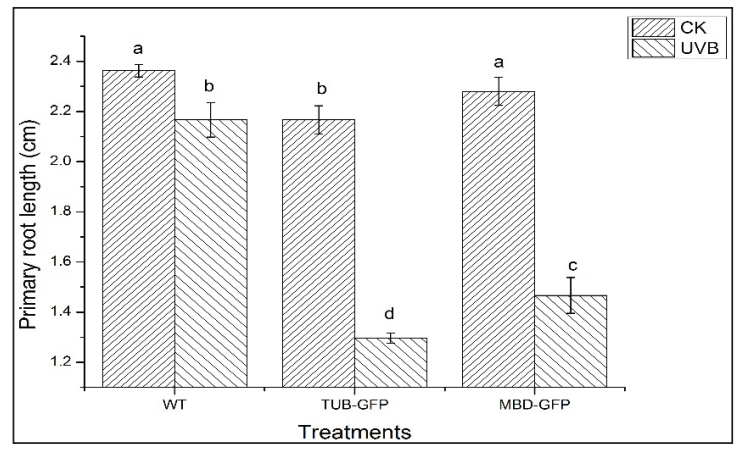

Figure 3- Comparison between the primary root length of $T U B-G F P$ and $M B D-G F P$ exposed to UV-B radiation, data represent the mean $\pm S D(n=3)$

Şekil 3- UV-B ışığına maruz bırakılmış TUB-GFP ve MBD-GFP bitkilerinin ana kök uzunluklarının karşılaştırılması, ortalama $\pm S D(n=3)$

\subsection{In vivo visualization of microtubules in TUB- GFP and MBD-GFP under UV-B treatment.}

Based on the results described above, we compared the microtubule dynamics of $T U B-G F P$ and $M B D-$ $G F P$ in response to UV-B treatment by confocal microscopy. In this experiment, we observed the microtubule dynamics of stomata. Total fluorescence was intense in $T U B-G F P$, and guard cells were symmetrical in the absence of UV-B (Figure 4a). However, UV-B treatment caused severe depolymerization of MTs and a reduction in total fluorescence in TUB-GFP. Guard cells were asymmetric, twisted and patched MTs were observed in stomata (Figure $4 \mathrm{a}^{\prime}$ ). By contrast, MTs in guard cells of $M B D-G F P$ appeared radial and fluorescence intensity was high without UV-B (Figure 4b). Exposure to UV-B caused the appearance of spots, the depolymerization of MTs, and a reduction in fluorescence in guard cells of $M B D-G F P$ (Figure $\left.4 b^{\prime}\right)$. 


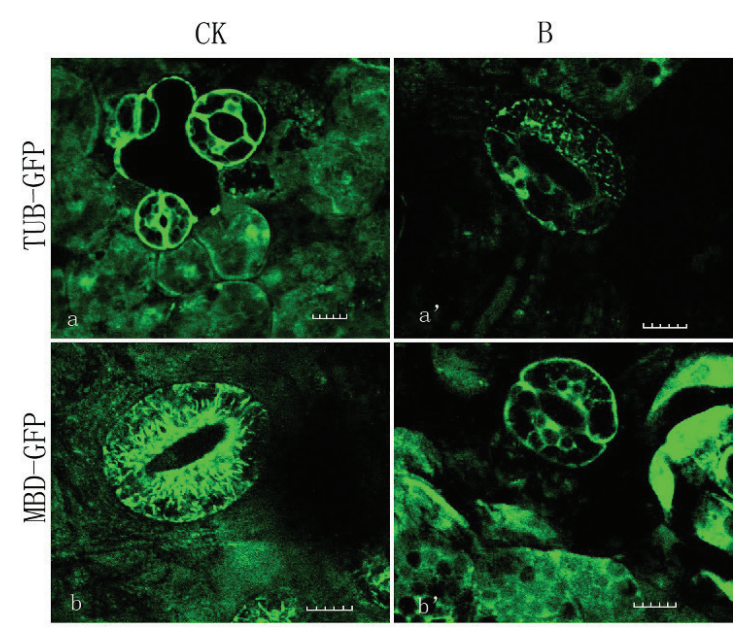

Figure 4- Microtubule dynamics of stomata in $T U B$ $G F P$ and $M B D-G F P$ exposed to UV-B radiation (Scale bar $=10 \mu \mathrm{m}) ; \mathrm{a}, \mathrm{a}^{\prime}$ show the microtubule dynamics of stomata in $T U B-G F P$ without $U V-B$ treatment (CK) and with UV-B treatment (B), respectively; $b, b^{\prime}$ show the microtubule dynamics of stomata in $M B D-G F P$ without $U V-B$ treatment (CK) and with UV-B treatment (B), respectively

Şekil 4- UV-B ışığına maruz bırakılmış TUB-GFP and MBD-GFP stomalarında mikrotubulüs hareketi

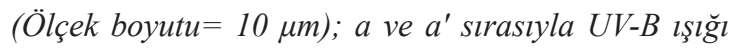
uygulanmamış (CK) ve UV-B uygulanmış (B) TUB-GFP stomalarındaki mikrotubulüs hareketi; $b$ ve $b^{\prime}$ strastyla $U V-B$ ışığı uygulanmamış (CK) ve $U V-B$ uygulanmış (B) MBD-GFP stomalarındaki mikrotubulüs hareketi

\section{Discussion}

The effects of UV-B radiation have attracted significant attention. UV-B radiation inhibits the growth and development of plants, and causes changes in architecture, such as curled leaves and other leaf changes, shorter petioles, and decreased stem elongation among others (Robson \& Aphalo 2012; Robson et al 2015). Hectors et al (2010) reported that UV-B resulted in transient changes in the length: width ratio of $A$. thaliana leaves. In the present study, the same characteristics were observed in the transgenic $A$. thaliana TUB-GFP and $M B D-G F P$; however, the extent of the changes was different (Figure 1). Previous studies suggested that
UV-B decreases stem elongation and inhibits root growth (Jansen 2002; Robson et al 2015), which is consistent with the present results shown in Figure 2 and 3. These phenotypes reflect the resistance to stress in plants and their protective effects in response to UV-B stress. The phenotypes of $T U B-$ $G F P$ and $M B D-G F P$ exposed to UV-B indicate damage to MTs caused by UV-B, and this damage was more severe in TUB-GFP than in MBD-GFP. These results support that MTs play a critical role in the growth of plants and their adaptation to the environment, and could be used as an indicator of UV-B associated damage.

Leaves are the principal direct recipient site in plants exposed to UV-B, and the responses of leaves to UV-B, and the effects of UV-B on stomata were significant. Therefore, we observed the MT dynamics of stomata in our study. In Figure $4 a^{\prime}$, guard cells appeared asymmetric and showed a deformed kidney shape, with patches and depolymerization of MTs under UV-B, compared with Figure 4a. In Figure 4a, MTs were not arranged radially, which may be caused by stomatal movement (Yu et al 2001; Lucas et al 2006). Figure $4 b^{\prime}$ shows depolymerization of MTs and their disappearance compared with Figure 4b. MTs are necessary for maintaining the kidney shape of guard cells (Yu et al 2001). Under UV-B stress, MTs aggregated in MBD-GFP, whereas they appeared patched and depolymerized, leading to slower growth in TUB-GFP. These results indicated that depolymerization of MTs is one of the main factors leading to the effects described above, and $M B D-G F P$ could be better adapted to the changes induced by UV-B.

Studies have shown that UV-B induces MT depolymerization and leads to a series of effects (Guo et al 2010; Krasylenko et al 2012; Krasylenko et al 2013). However, the mechanisms of depolymerization of MTs under UV-B remain unclear. Abiotic stress is one of the factors causing MT reorientation, such as drought, turgor pressure, and osmotic stress (Bisgrove 2008; Hong et al 2010; Liu et al 2014). Turgor pressure maintains cell tension, regulates stomatal opening and closing, and is closely related to the growth of plant cells. At the 
same time, turgor pressure regulates MTs (Iwata et al 2001; Yu et al 2001; Liu et al 2014). When stomata close, fewer MT structures are detected in guard cells and MTs are disassembled (Eisinger et al 2012). UV-B could change the membrane permeability of guard cells, and induce stomatal closure (Zhang \& Zhou 2009). Therefore, MTs are closely related to turgor pressure, and MTs can be altered under UV-B, leading to changes in plants. This implies that UV-B may indirectly affect turgor pressure and lead to changes of MT dynamics, causing changes in the plants.

\section{Acknowledgements}

Thank Professor Rong HAN for the guidance. The work was supported by the National Nature Science Foundation of China (No. 30671061) and the Natural Science of Shanxi Province (Nos. 20081101, 2014011028-5). We thank Dongtao REN (China Agricultural University) for kindly providing the TUB-GFP Arabidopsis seeds. At the same time, we thank Tonglin MAO (China Agricultural University) for kindly providing the $M B D-G F P$ Arabidopsis seeds.

\section{References}

Bisgrove S R (2008). The roles of microtubules in tropisms. Plant Science 175(6): 747-755

Chen H \& Han R (2015). F-actin participates in the process of the "partition-bundle division". Russian Journal of Plant Physiology 62(2): 187-194

Cleary A L \& Hardham A R (1993). Pressure induced reorientation of cortical microtubules in epidermal cells of Lolium rigidum leaves. Plant and Cell Physiology 34(7): 1003-1008

Eisinger W, Ehrhardt D \& Briggs W (2012). Microtubules are essential for guard-cell function in Vicia and Arabidopsis. Molecular Plant 5(3): 601-610

Granger C L \& Cyr R J (2000). Microtubule reorganization in tobacco BY-2 cells stably expressing GFP-MBD. Planta 210: 502-509

Granger C L \& Cyr R J(2001). Spatiotemporal relationships between growth and microtubule orientation as revealed in living root cells of Arabidopsis thaliana transformed with green-fluorescent-protein gene construct GFP-MBD. Protoplasma 216(3-4): 201-214

Guo A H, Gao L M, Li Y F \& Han R (2010). Influence on microtubule in wheat mesophyll cell exposed to enhanced ultraviolet-B radiation and $\mathrm{He}-\mathrm{Ne}$ laser irradiation. Guihaia 30(2): 250-255

Han R, Wang X, Yue M \& Qi Z (2002). Effects of the enhanced UV-B radiation on the body cell mitosis of the wheat. Acta Genetica Sinica 29(6): 537-541

Hardham A R, Takemoto D \& White R G (2008). Rapid and dynamic subcellular reorganization following mechanical stimulation of Arabidopsis epidermal cells mimics responses to fungal and oomycete attack. BMC Plant Biology 8(63): 1-14

Hectors K, Jacques E, Prinsen E, Guisez Y, Verbelen J P, Jansen M A \& Vissenberg K (2010). UV radiation reduces epidermal cell expansion in leaves of Arabidopsis thaliana. Journal of Experimental Botany 61(15): 4339-4349

Hong Y Y, Zhang W H \& Wang X M (2010). Phospholipase $\mathrm{D}$ and phosphatidic acid signalling in plant response to drought and salinity. Plant, Cell \& Environment 33(4): 627-635

Iwata K, Tazawa M \& Itoh T (2001). Turgor pressure regulation and the orientation of cortical microtubules in Spirogyra cells. Plant and Cell Physiology 42(6): 594-598

Jansen M A (2002). Ultraviolet-B radiation effects on plants: İnduction of morphogenic responses. Physiologia Plantarum 116(3): 423-429

Kawamura E \& Wasteneys G O (2008). MOR1, the Arabidopsis thaliana homologue of Xenopus MAP215, promotes rapid growth and shrinkage, and suppresses the pausing of microtubules in vivo. Journal of Cell Science 121: 4114-4123

Krasylenko Y A, Yemets A I, Sheremet Y A \& Blume Y B (2012). Nitric oxide as a critical factor for perception of UV-B irradiation by microtubules in Arabidopsis. Physiologia Plantarum 145(4): 505-515

Krasylenko Y A, Yemets A I \& Blume Y B (2013). Plant microtubules reorganization under the indirect UV-B exposure and during UV-B-induced programmed cell death. Plant Signaling \& Behavior 8(5): e24031, doi: $10.4161 / \mathrm{psb} .24031$

Liu J Y, Wang B C, Zhang Y G, Wang Y C, Kong J, Zhu L Q, Yang X Y \& Zha G D (2014). Microtubule dynamics is required for root elongation growth 
under osmotic stress in Arabidopsis. Plant Growth Regulation 74: 187-192

Lucas J R, Nadeau J A \& Sack F D (2006). Microtubule arrays and Arabidopsis stomatal development. Journal of Experimental Botany 57(1): 71-79

Marc J, Granger C L, Brincat J, Fisher D D, Kao T, McCubbin A G \& Cyr R J (1998). A GFP-MAP4 reporter gene for visualizing cortical microtubule rearrangements in living epidermal cells. The Plant Cell 10(11): 1927-1939

Nakamura M, Naoi K, Shoji T \& Hashimoto T (2004). Low concentrations of propyzamide and oryzalin alter microtubule dynamics in Arabidopsis epidermal cells. Plant and Cell Physiology 45(9): 1330-1334

Robson T M \& Aphalo P J (2012). Species-specific effect of UV-B radiation on the temporal pattern of leaf growth. Physiologia Plantarum 144(2): 146-160

Robson T M, Klem K, Urban O \& Jansen M A (2015). Reinterpreting plant morphological responses to UV-B radiation. Plant, Cell \& Environment 38(5): 856-866

Rozema J, Staaij J V, Björn L O \& Caldwell M (1997). UV-B as an environmental factor in plant life: stress and regulation. Trends in Ecology \& Evolution 12(1): $22-28$
Sedbrook J C (2004). MAPs in plant cells: Delineating microtubule growth dynamics and organization. Current Opinion in Plant Biology 7(6): 632-640

Shi L C, Wang B C, Gong W, Zhang Y G, Zhu L Q \& Yang X Y (2011). Actin filaments and microtubules of Arabidopsis suspension cells show different responses to changing turgor pressure. Biochemical and Biophysical Research Communications 405(4): 632-637

Voigt B, Timmers A C, Šamaj J, Müller J, Baluška F \& Menzel D (2005). GFP-FABD2 fusion construct allows in vivo visualization of the dynamic actin cytoskeleton in all cells of Arabidopsis seedlings. European Journal of Cell Biology 84(6): 595-608

Wasteneys G O \& Yang Z B (2004). New views on the plant cytoskeleton. Plant Physiology 136(4): 38843891

Yu R, Huang R F, Wang X C \& Yuan M (2001). Microtubule dynamics are involved in stomatal movement of Vicia faba L. Protoplasma 216: 113-118

Zhang J W \& Zhou Q (2009). Effect of UV-B radiation on water metabolism in plants (in Chinese). Chinese Journal of Eco-Agriculture 17(4): 829-833 